\title{
CRITICAL LIMITS OF SOIL PENETRATION RESISTANCE IN A RHODIC EUTRUDOX ${ }^{(1)}$
}

\author{
Moacir Tuzzin de Moraes ${ }^{(2)}$, Henrique Debiasi ${ }^{(3)}$, Reimar Carlesso(4), Julio Cezar \\ Franchini $^{(3)}$ \& Vanderlei Rodrigues da Silva ${ }^{(5)}$
}

\begin{abstract}
SUMMARY
Soil penetration resistance is an important indicator of soil physical quality and the critical limit of $2 \mathrm{MPa}$ has been widely used to characterize the soil physical quality, in both no-tillage and conventional systems. The aim of this study was to quantify the influence of different tillage and cropping systems on the soil penetration resistance in a Rhodic Eutrudox. The experiment was carried out in a $5 \times \mathbf{2}$ factorial, completely randomized block design (tillage systems $v s$ cropping systems), with four replications. The tillage systems consisted of: conventional tillage disk harrow; minimum tillage with annual chiseling; minimum tillage with chiseling every three years; no-tillage for 11 consecutive years; and no-tillage for 24 consecutive years. The factor cropping systems was represented by: crop rotation and crop succession. The soil penetration resistance (SPR) was determined in 20 soil samples per treatment and layer $(0.0-0.10 ; 0.10-0.20$ and $0.20-0.30 \mathrm{~m})$ for each soil matric potential: $-6,-10,-33,-100,-500 \mathrm{kPa}$. The SPR was determined at a volumetric soil water content equivalent to the fraction of plant-available water of 0.7. There were no differences of soil penetration resistance between the two cropping systems. Differences in soil penetration resistance among tillage systems were related to the matric potential at which the samples were equilibrated. The critical SPR limit of 2 MPa normally used for conventional tillage should be maintained. However, this value of $2 \mathrm{MPa}$ is inappropriate for the physical quality characterization of Rhodic Eutrudox under no-tillage and/or minimum tillage with chiseling. Regardless of the cropping systems, the critical SPR limit should be raised to $3 \mathrm{MPa}$ for minimum tillage with chiseling and to 3.5 MPa for no-tillage.
\end{abstract}

Index terms: no-tillage, soil chiseling, level compaction.

(1) Part of the Master's dissertation of the first author submitted at Federal University of Santa Maria (UFSM) and Embrapa Soja. Received for publication February 26, 2013 and approved September 19, 2013.

(2) Doctoral student, Post-Graduation course in Soil Science, Federal University of Rio Grande do Sul - UFRGS. Av. Bento Gonçalves, 7712, Prédio 41506. CEP 91540-000 Porto Alegre (RS), Brazil. E-mail: moacir.tuzzin@gmail.com

(3) Researcher, Embrapa Soja. Rod. Carlos João Strass, Distrito de Warta. Caixa Postal 231. CEP 86001-970 Londrina (PR), Brazil. E-mail: henrique.debiasi@embrapa.br, julio.franchin@embrapa.br

(4) Professor, Department of Rural Engineering at the UFSM, Rural Sciences Center - CCR, Campus UFSM. Rua Q, 68, Camobi. CEP 97105-900 Santa Maria (RS), Brazil. Email: carlesso@ccr.ufsm.br

(5) Professor, Department of Environment and Agronomy Science, UFSM. Campus de Frederico Westphalen. Linha Sete de Setembro, s/n. Rod. BR 386, km 40. CEP 98400-000 Frederico Westphalen (RS), Brazil. E-mail: vanderlei@ufsm.br 


\title{
RESUMO: LIMITES CRÍTICOS DE RESISTÊNCIA À PENETRAÇÃO EM UM LATOSSOLO VERMELHO DISTROFÉRRICO
}

\begin{abstract}
A resistência do solo à penetração é um importante indicador da qualidade física do solo, e o limite crítico de 2 MPa vem sendo utilizado para caracterizar a qualidade física do solo, tanto em sistema plantio direto como em cultivos convencionais. Objetivou-se com este trabalho verificar a influência de diferentes sistemas de manejo do solo e modelos de produção sobre a SPR em um Latossolo Vermelho distroférrico. O experimento foi conduzido em um delineamento de blocos ao acaso, em esquema fatorial $5 \times 2$ (manejos do solo $\times$ modelos de produção), com quatro repetições. Os manejos do solo foram: sistema preparo convencional; sistema preparo mínimo escarificado a cada ano; sistema preparo mínimo escarificado a cada três anos; sistema plantio direto contínuo por 11 anos; e sistema plantio direto contínuo por 24 anos. $O$ fator modelo de produção foi composto por: rotação e sucessão de culturas. A resistência do solo à penetração foi determinada em 20 amostras indeformadas de solo por tratamento e por camada $(0,0-0,10 ; 0,10-0,20$ e 0,20-0,30 m), as quais foram equilibradas nos potenciais matriciais de -6, -10, -33, -100 e -500 kPa. Foi determinada a resistência do solo à penetração no conteúdo de água volumétrico equivalente à fração de água disponível às plantas de 0,7. Não houve diferenças de resistência do solo à penetração entre os modelos de produção. A detecção de diferenças de resistência do solo à penetração entre os sistemas de manejo do solo foi dependente do potencial matricial de água no solo, em que as amostras foram equilibradas. O limite crítico de resistência do solo à penetração usualmente utilizado de 2 MPa deve ser mantido para o sistema preparo convencional. Todavia, esse valor foi inadequado para a caracterização da qualidade física do Latossolo Vermelho distroférrico, sob sistema plantio direto e, ou, no sistema de preparo mínimo. Independentemente do modelo de produção, os limites crítico de resistência do solo à penetração devem ser ampliados para 3 MPa, no sistema preparo mínimo com escarificação, e para 3,5 MPa, no sistema plantio direto.
\end{abstract}

Termos de indexação: sistema plantio direto, escarificação do solo, nível de compactação.

\section{INTRODUCTION}

No-tillage (NT) has been increasingly used due to the numerous economic and agronomic advantages such as soil and water conservation and improved crop yield (Silva et al., 2012). However, some reports in literature have shown that NT has led to the formation of a layer characterized by a high compaction level, generally located between 0.10 and $0.20 \mathrm{~m}$ deep in the soil (Franchini et al., 2009). Apart from increasing soil resistance to root penetration (Moraes et al., 2012, 2013) and limiting the depth and volume of soil explored by plant roots for water and nutrients (Bergamin et al., 2010), soil compaction reduces total porosity, macroporosity, aeration, infiltration capacity (Dias Junior \& Pierce, 1996), and saturated hydraulic conductivity (Silva et al., 2009).

Soil penetration resistance (SPR) has been used by several researchers to quantify the soil quality and to identify the layers with increased degree of compaction (Franchini et al., 2011; Moraes et al., 2013). In making management decisions to solve soil compaction problems under NT, fixed SPR values considered limiting have been proposed and used (Reichert et al., 2007; Betioli Júnior et al., 2012), regardless of the soil type or tillage system. Although the most commonly used value is $2 \mathrm{MPa}$ (Tormena et al., 1998; Silva et al., 2008; Lima et al., 2012), recent research results have shown the possibility of increasing the limiting value of SPR to 3.5 MPa under consolidated NT conditions, due to the presence of continuous and biological pores, which favor root growth even in areas with low SPR (Tormena et al., 2007; Betioli Júnior et al., 2012). However, there are still doubts about which SPR level ought to be used as critical or limiting under long-term NT, because in areas where the measured SPR reflects a high level of soil compaction, the grain yield is not affected. This shows that these SPR thresholds may be inadequate. Therefore, it is possible that the limiting values of SPR to root growth vary according to the tillage system.

Soil management practices to control soil compaction with periodic plowing and chiseling have been tested by several authors (Tavares Filho et al., 2006; Silva et al., 2012). However, the residual effect of these interventions on soil physical properties usually disappeared after a few crop cycles (Drescher et al., 2011), sometimes in less than six months (Silva et al., 2012) or after one year (Tavares Filho et al., 2006). Another measure that has been recommended to improve the physical quality of compacted soils involves the adoption of cropping systems that include plants with a high biomass production potential and characterized by an abundant, deep and aggressive root system (Franchini et al., 2011).

Although the effect of crop rotation on soil physical quality in NT has been the subject of several studies (Genro Junior et al., 2009; Lanzanova et al., 2010; Debiasi et al., 2010; Costa et al., 2011), there are still doubts about the efficiency of this practice in 
mitigating soil compaction. This is because the benefits of crop rotation on soil physical quality are not always detectable, as most of these studies were conducted on a short- or medium-term basis, regardless of the time adoption of the NT.

Therefore, the objectives of this study were to evaluate the effects of different tillage and cropping systems on SPR in a Rhodic Eutrudox with very clayey texture and identify the need to alter the critical limit of SPR of $2 \mathrm{MPa}$ for the evaluation of soil physical quality as a function of soil management.

\section{MATERIAL AND METHODS}

\section{Study site}

This long-term experiment was established in 1988 at the Experimental Station of Embrapa Soybean, in Londrina, State of Paraná, Southern Brazil (Lat. $23^{\circ} 11^{\prime} \mathrm{S}$; Long. 51 ${ }^{\circ} 11^{\prime} \mathrm{W} ; 620 \mathrm{~m}$ asl). According to the Köppen classification, the regional climate is Subtropical Humid, Mesothermal (Cfa), with a mean annual temperature of $20{ }^{\circ} \mathrm{C}$ and $1,622 \mathrm{~mm}$ rainfall. The soil of the study area is basaltic and was classified as Latossolo Vermelho distroférrico (Brazilian soil classification) (Santos et al., 2013), or Rhodic Eutrudox (American soil classification) (Soil Survey Staff, 2010) with very clayey texture.

\section{Experimental design and treatments}

The experiment had a $5 \times 2$ factorial design (tillage systems $x$ cropping systems), distributed in a randomized block design with four replications. The treatments consisted of the following tillage systems: conventional tillage with heavy plowing to a depth of $0.15 \mathrm{~m}$, then light harrowing before each winter and summer growing season (CT); minimum tillage with annual chiseling $\left(\mathrm{MTC}_{1}\right)$; minimum tillage with chiseling every three years $\left(\mathrm{MTC}_{3}\right)$; continuous $\mathrm{NT}$ for 11 years, established in $2001\left(\mathrm{NT}_{11}\right)$; and continuous NT for 24 years, established in 1988 $\left(\mathrm{NT}_{24}\right)$. Between 1988 and 2001, the soil in $\mathrm{NT}_{11}$ was tilled with a moldboard plow (average working depth of $0.32 \mathrm{~m}$ ), followed by harrowing before planting the summer crop, and heavy harrowing (average working depth of $0.15 \mathrm{~m}$ ) followed by light disking before planting the winter crop. The $\mathrm{MTC}_{1}$ and $\mathrm{MTC}_{3}$ plots were chiseled before planting the winter crops, using a mounted chisel plow with rollers and four shanks spaced $0.40 \mathrm{~m}$ apart, working at an average depth of $0.30 \mathrm{~m}$ and an angle of $45^{\circ}$. The two cropping systems were: wheat succession (Triticum aestivum L.) in winter and soybean (Glycine $\max$ (L.) Merr.) in summer and, four-year crop rotation system, with the following species: white lupine (Lupinus albus L.) or radish (Raphanus sativus L.)/maize (Zea mays L.); white oat (Avena strigosa Schreb.)/soybean; wheat/ soybean; and wheat/soybean in winter/summer rotation, respectively. The $30 \times 10 \mathrm{~m}$ plots were spaced $7 \mathrm{~m}$ from each other to ensure tractor turning during operations. The average dry biomass production of the species in succession and crop rotation systems was approximately 5.3 and $7 \mathrm{Mg} \mathrm{ha}^{-1} \mathrm{yr}^{-1}$, respectively. The average initial soil organic carbon content in the 0.0-0.10 m layer was 18.9, 19.9, 19.8, 20.6 and $21.9 \mathrm{~g} \mathrm{~kg}^{-1}$ in CT, $\mathrm{MTC}_{1}, \mathrm{MTC}_{3}, \mathrm{NT}_{11}$ and $\mathrm{NT}_{24}$, respectively. Details of the soil physical and chemical characteristics of the site before the establishment of the experiment were reported by Piccinin (2005).

\section{Soil sampling}

The soil was sampled 10 and 22 months after the last chiseling in $\mathrm{MTC}_{1}$ and $\mathrm{MTC}_{3}$ plots, respectively. Soil profiles were opened in each treatment between crop rows during summer (soybean) and a total of 600 undisturbed samples were collected from the layers $0.0-0.10,0.10-0.20$ and $0.20-0.30 \mathrm{~m}$ with core samplers (internal diameter $5.0 \mathrm{~cm}$, height $5.0 \mathrm{~cm}$ ). The samples were collected at soil moisture content near field capacity, with a soil sampler device coupled to a tractor, to ensure that the core samplers were vertically inserted and the samples sequentially collected from the center of each soil layer.

\section{Determination of soil physical, mechanical and hydraulic properties}

The 600 soil samples were divided into five groups of 120 soil samples, totalizing eight undisturbed samples per tillage systems and layers, regardless of the cropping systems. Samples were saturated and subjected to the following matric potential of water in soil ( $\Psi)$ : -3 and $-6 \mathrm{kPa}$ on a tension table (Embrapa, 1997) and -10, -33, -100, and -500 kPa, using Richards' pressure plate apparatus. After reaching equilibrium at each water tension, the soil samples were weighed and with the exception of $\Psi$ of $-3 \mathrm{kPa}$, the samples were subjected soil penetration tests to determine the SPR, using a static penetrometer (Marconi, model MA 933) consisting of a metallic rod (diameter $4 \mathrm{~mm}$, base area $0.1256 \mathrm{~cm}^{2}$, cone half angle of $30^{\circ}$ and penetration rate of $20 \mathrm{~mm} \mathrm{~min}^{-1}$ ). The soil samples were oven-dried at $105^{\circ} \mathrm{C}$ for $24 \mathrm{~h}$ to quantify the soil bulk density (BD) and volumetric soil water content $(\theta)\left(\mathrm{m}^{3} \mathrm{~m}^{-3}\right)$.

The gravimetric soil water content at $\Psi$ of $-1500 \mathrm{kPa}$ was determined in disturbed soil samples passed through a 2-mm sieve with a dew-point psychrometer (model WP4-C) (Klein et al., 2006). Thus, $\theta$ at this $\Psi$ $(-1500 \mathrm{kPa})$ was determined from the gravimetric soil water content and BD.

Using the SPR curve of each tillage systems, as described by Moraes (2013), the SPR was determined at $\theta$ equivalent to the fraction of plant-available water (PAW) of 0.7. The PAW is the ratio of the actual and the potential water storage capacity of the soil (Santos $\&$ Carlesso, 1998). For the potential water storage 
capacity of the soil, the values of è between field capacity (FC), at a $\Psi$ of $-10 \mathrm{kPa}$, and permanent wilting point (PWP), at a $\Psi$ of $-1500 \mathrm{kPa}$, were considered. The $\theta$ values for $\Psi$ between $\mathrm{FC}$ and $\mathrm{PWP}$ were estimated using the water retention curve for each tillage system, as described by Moraes (2013).

The results of SPR and $\theta$ were subjected to analysis of variance $(p<0.05)$, separately for each layer (0.0-0.10, 0.10-0.20 and 0.20-0.30 $\mathrm{m})$ and $\Psi(-6,-10$, $33,-100,-500 \mathrm{kPa})$. When the treatment effects were significant, means were compared by Tukey's test at $5 \%$ probability. Data analyses were performed using the computer program Statistical Analysis System (SAS, 2002).

\section{RESULTS AND DISCUSSION}

The interaction between the soil management systems and cropping systems was not significant for any of the variables in the three layers of the soil profile. Thus, the simple effect of each of the factors (tillage and cropping systems) was compared in the layers 0.0-0.10, 0.10-0.20 and 0.20-0.30 m.

Clearly, the volumetric soil water content $(\theta)$ decreased with the increase in matric potential $(\Psi)$ (Figure 1-I). There was no significant influence of cropping systems on water retention in all layers evaluated, however the increasing trend of SPR as a function of $\Psi$ can be attributed to the reduction in $\theta$, which agrees with the exponential increase in SPR due to the reduction of the gravimetric soil water content (Moraes et al., 2012, 2013).

The effects of the cropping systems on SPR were small, regardless of $\Psi$ (Figure 1-II). The SPR was significantly higher in the crop rotation than succession system in the 0.0-0.10 m layer at $\Psi$ of $-6 \mathrm{kPa}$ (Figure 1a-II), and in the $0.20-0.30 \mathrm{~m}$ layer at $\Psi$ of $-33 \mathrm{kPa}$ (Figure 1c-II). At the other $\Psi$ values, SPR was not affected by cropping systems. This result was consistent with the absence of significant effects of cropping systems on the other soil physical properties evaluated (Moraes, 2013), showing that SPR, a property considered highly sensitive to soil structural alterations induced by different management practices (Abreu et al., 2004), must not be used to differentiate between crop rotation and succession. Abreu et al. (2004) evaluated the breaking of compacted layers by chiseling or plants with an aggressive root system and concluded that the resulting improvements in soil physical conditions depend on the physical property used. Based on soil hydraulic conductivity, these authors observed that biological chiseling of the soil was more effective than mechanical chiseling, with the opposite result when using SPR as indicator.

In the layers below $0.10 \mathrm{~m}$, it was observed that at $\Psi$ of $-10 \mathrm{kPa}$ (field capacity), both the crop rotation and succession systems reached the critical SPR level of $2 \mathrm{MPa}$ (Figure 1a-II). This shows that at soil water contents below field capacity, based on the criterion of SPR of $2 \mathrm{MPa}$, the physical conditions would be restrictive to crop growth and development.

Except at $\Psi$ of $-10 \mathrm{kPa}, \theta$ was influenced by the management systems (Figure 2-I). In general, the management systems with greater tillage intensity $\left(\mathrm{CT}\right.$ and $\left.\mathrm{MTC}_{1}\right)$ resulted in lower values of $\theta$ than the other treatments, which was most evident in the 0.0-0.10 m layer. These differences in the $\theta$ values may have resulted in variations in SPR between the soil management systems. Furthermore, irrespective of the management system and $\Psi$, there was an increase in $\theta$ with soil depth, suggesting the existence of alterations in the pore size distribution within the soil profile.

The SPR values were influenced by the variation of $\theta$ at each $\Psi$ value and by the soil management systems (Figure 2-II). The reduction in SPR due to the increase in $\theta$ is reflected in the $\Psi$ values. This reduction in SPR at high water contents is possibly the result of the presence of water which facilitates penetration of the rod by its lubricating action between the particles (Assis et al., 2009). Furthermore, an increase in $\theta$ causes reduction of friction as well as cohesion forces between soil particles and aggregates, resulting in a decrease in SPR (Ros et al., 2011).

At $\Psi,-6$ and $-10 \mathrm{kPa}$ (Figure 2a, b-II), the average SPR values of the tillage systems were close to $2 \mathrm{MPa}$. However, reduction of $\Psi$ below -33 kPa (Figure 2c-II) resulted in SPR above $2 \mathrm{MPa}$, with the exception of the 0.0-0.10 m layer in the CT treatment. Even when determined at high $\theta$ (field capacity), the SPR values were close to or greater than $2 \mathrm{MPa}$ in all tillage systems under NT, including in the recently tilled $\left(\mathrm{MTC}_{1}\right.$ and $\left.\mathrm{MTC}_{3}\right)$, demonstrating clearly that $2 \mathrm{MPa}$ is inappropriate as critical threshold for this Rhodic Eutrudox.

In the 0.0-0.10 $\mathrm{m}$ layer, the SPR values were lower in treatment CT than in the other tillage systems (Figure 2-II) at virtually all $\Psi$ values, demonstrating the effect of disruption of the soil structure by the use of a disk harrow. In this layer, on the other hand, there were no differences between the times of adoption of $\mathrm{NT}\left(\mathrm{NT}_{11}\right.$ and $\left.\mathrm{NT}_{24}\right)$ compared with $\mathrm{MTC}_{1}$ and $\mathrm{MTC}_{3}$. This indicates that the effects of soil chiseling persisted less than 10 months.

In the 0.10-0.20 m layer, SPR was in most cases higher in CT than $\mathrm{MTC}_{1}$, clearly demonstrating the effect of the formation of a "tillage pan" below a depth of $0.10 \mathrm{~m}$ in CT. In the same layer, no significant differences in SPR were observed between treatments $\mathrm{MTC}_{1}$ and $\mathrm{MTC}_{3}$, in all situations evaluated (Figure 2c,e-II), however, it is noteworthy that, in both situations, the $\theta$ of $\mathrm{MTC}_{1}$ was lower than $\mathrm{MTC}_{3}$ (Figure 2c,e-I), which can contribute to marked differences in SPR between the treatments (Moraes et al., 2012). Similarly, there were no differences in 


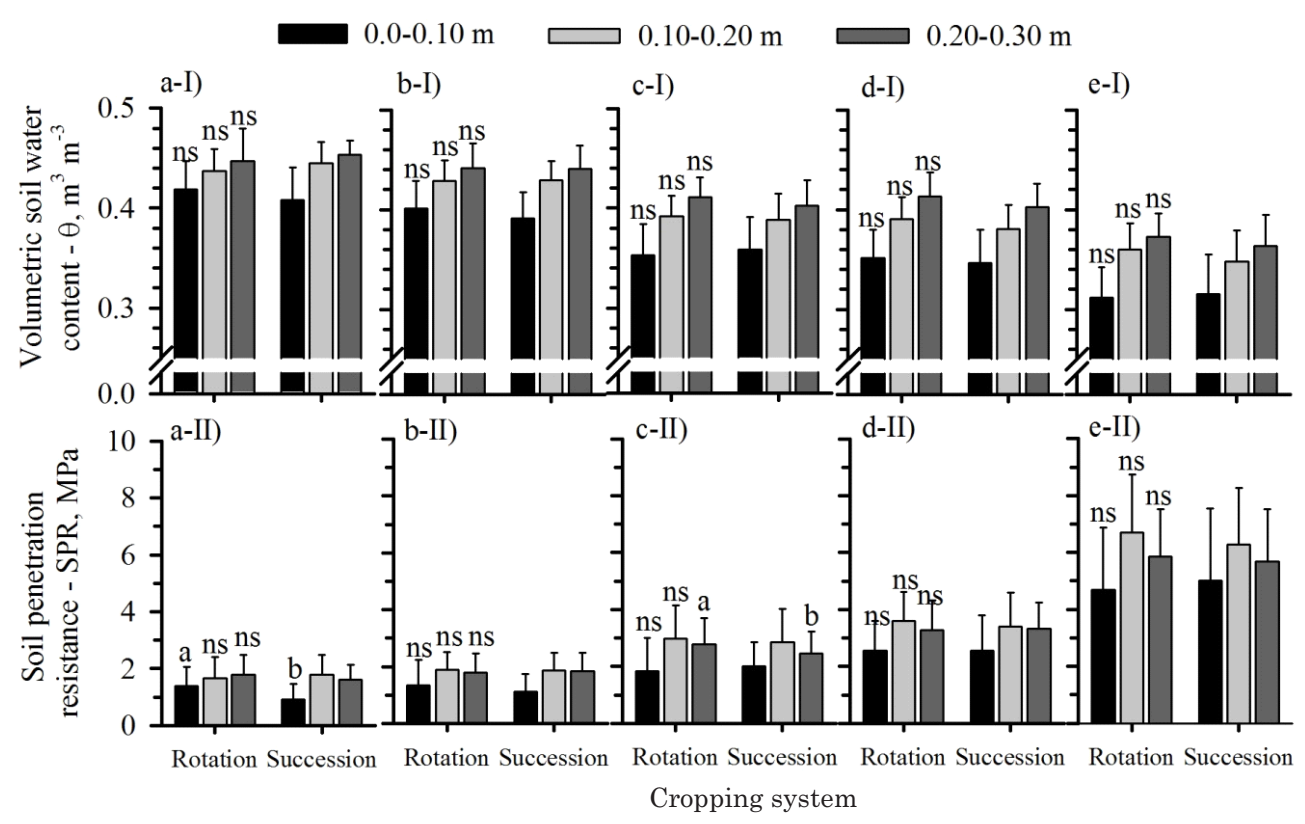

Figure 1. Volumetric soil water content (I) and soil penetration resistance (II) as function of cropping systems, determined at matrix potential of $-6 \mathrm{kPa}(\mathrm{a}),-10 \mathrm{kPa}(\mathrm{b}),-33 \mathrm{kPa}(\mathrm{c}),-100 \mathrm{kPa}(\mathrm{d})$ and $-500 \mathrm{kPa}$ (e). ns Not significant by the F-test $(p<0.05)$. Means followed by the same letter in the same layer do not differ by the Tukey test $(p<0.05)$. Vertical bars indicate standard deviation from the mean.

SPR values between the no-tillage periods, showing no increase in the compaction degree over time (Figure 2-II). This indicates that the soil physical quality of $\mathrm{NT}$ can be maintained over time without requiring mechanical soil tillage.

In the 0.10-0.20 $\mathrm{m}$ layer, the differences between the SPR values in treatment $\mathrm{MTC}_{1}$ and the NT system $\left(\mathrm{NT}_{11}\right.$ and $\left.\mathrm{NT}_{24}\right)$ were altered as a function of $\Psi$ (Figure 2-II). At $\Psi$ of - $500 \mathrm{kPa}$ (Figure 2e-II), SPR was significantly lower in $\mathrm{MTC}_{1}$ than $\mathrm{NT}_{11}$. The $\mathrm{MTC}_{1}$ resulted in lower SPR values in relation to $\mathrm{NT}_{24}$ at $\Psi$ of $-6,-10$ and $-100 \mathrm{kPa}$ (Figure $2 \mathrm{a}, \mathrm{b}, \mathrm{d}-\mathrm{II})$. This shows that in this layer, the reduction in SPR by soil chiseling was detectable up to 10 months after application. On the contrary, there were no significant differences between $\mathrm{MTC}_{3}$ and continuous no-tillage $\left(\mathrm{NT}_{11}\right.$ and $\left.\mathrm{NT}_{24}\right)$, except at $\Psi$ of $-100 \mathrm{kPa}$, where SPR was significantly higher in $\mathrm{NT}_{24}$ (Figure $2 \mathrm{~d}$-II). Thus, 22 months after soil chiseling, it was impossible to detect residual effects of this practice on SPR.

In the 0.20-0.30 m layer, significant differences were also observed for SPR results among the management systems as a function of $\Psi$ (Figure 2II). In all cases, there were no differences in SPR between treatments with periodic soil chiseling $\left(\mathrm{MTC}_{1}\right.$ and $\mathrm{MTC}_{3}$ ). Similar results were obtained between the period of $\mathrm{NT}$ installation $\left(\mathrm{NT}_{11}\right.$ and $\left.\mathrm{NT}_{24}\right)$. Comparing periodic soil chiseling $\left(\mathrm{MTC}_{1}\right.$ and $\left.\mathrm{MTC}_{3}\right)$ with no-tillage systems $\left(\mathrm{NT}_{11}\right.$ and $\left.\mathrm{NT}_{24}\right)$, significant differences were observed only when SPR was determined at $\Psi$ of $-100 \mathrm{kPa}$ (Figure $2 \mathrm{~d}-\mathrm{II})$. In this case, the SPR values were higher in $\mathrm{NT}_{24}$ than in
$\mathrm{MTC}_{1}$ and $\mathrm{MTC}_{3}$. The absence of differences in SPR between periodic soil chiseling $\left(\mathrm{MTC}_{1}\right.$ and $\left.\mathrm{MTC}_{3}\right)$ and continuous no-tillage $\left(\mathrm{NT}_{11}\right.$ and $\left.\mathrm{NT}_{24}\right)$ demonstrates the uselessness of periodic soil chiseling to reduce the compaction degree of this soil, since the effect persists for less than 10 months and soybeans and wheat yields are not increased compared to $\mathrm{NT}\left(\mathrm{NT}_{11}\right.$ and $\left.\mathrm{NT}_{24}\right)$, as reported by Moraes (2013) in a study conducted at the same location.

The existence of a soil layer with a greater degree of compaction, a "tillage pan" in CT was identified due to the sharp increase in SPR in the 0.20-0.30 m layer in relation to the surface layer (Figure 2-II). However, in this 0.20-0.30 m layer, the variations in $\mathrm{SPR}$ in CT plots in relation to other tillage systems are dependent on the varied values of $\theta$ at different $\Psi$. The SPR values in CT, evaluated at $\Psi$ equal to $-6 \mathrm{kPa}$, were higher than in all soil management. However, at other $\Psi$ values, no significant differences were observed in the 0.20-0.30 m layer between treatments $\mathrm{CT}$ and $\mathrm{NT}\left(\mathrm{NT}_{11}\right.$ and $\mathrm{NT}_{24}$ ), indicating that the reduction of $\theta$ may have altered the sensitivity of SPR to detect any increase in compaction level in treatment $\mathrm{CT}$ in relation to $\mathrm{NT}_{11}$ and $\mathrm{NT}_{24}$. Probably the absence of differences in the SPR values in $\mathrm{NT}_{24}$ compared with $\mathrm{CT}$ at $\Psi$ greater than $-6 \mathrm{kPa}$ may be related to soil structure formation in $\mathrm{NT}_{24}$, in which the aggregate bonding strength was higher, as well as having BD lower than CT (Moraes, 2013).

Concerning the possibility of raising the critical limits of SPR for this very clayey Oxisol, it was observed that the values of $\theta$ at which SPR reaches 2 


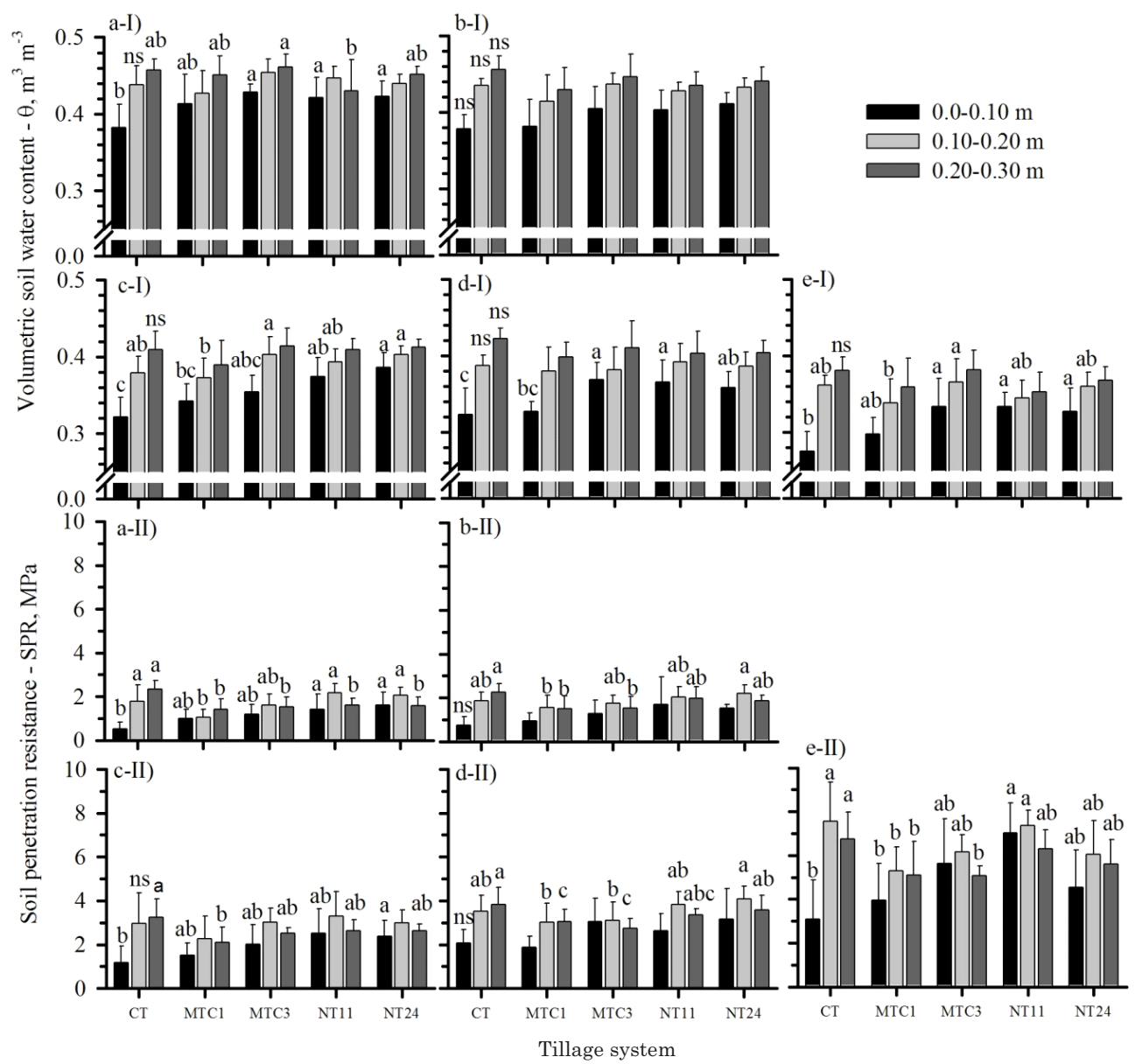

Figure 2. Volumetric soil water content (I) and soil penetration resistance (II) as a function of tillage systems, based on the matrix potential of $-6 \mathrm{kPa}(\mathrm{a}),-10 \mathrm{kPa}(\mathrm{b}),-33 \mathrm{kPa}(\mathrm{c})-100 \mathrm{kPa}(\mathrm{d})$ and $-500 \mathrm{kPa}(\mathrm{e})$. ns $\mathrm{Not}$ significant by the F-test $(p<0.05)$. Means followed by the same letter in the same layer do not differ by Tukey's test ( $\mathbf{p}<0.05)$. CT: conventional tillage system; MTC $_{1}$ : minimum tillage, annual chiseling; MTC $_{3}$ : minimum tillage, chiseled every three years; $\mathrm{NT}_{11}$ : no-tillage for 11 years; $\mathrm{NT}_{24}$ : no-tillage for 24 years. Vertical bars indicate the standard deviation from the mean value.

and 3.5 MPa were altered depending on the tillage systems (Figure $3-\mathrm{I}$ ) and independent of the cropping systems (Figure 3 -II). In the 0.0-0.10 m layer, the è at SPR of $2 \mathrm{MPa}$ was equal to $\theta$ at $\Psi$ of $-10 \mathrm{kPa}$ and higher than that at $\Psi$ of $-33 \mathrm{kPa}$ in treatment $\mathrm{NT}_{11}$. There were no significant differences between the $\theta$ values at $\Psi$ of $-33 \mathrm{kPa}$ and the $\theta$ values at SPR of $2 \mathrm{MPa}$ in $\mathrm{MTC}_{3}$ and $\mathrm{NT}_{24}$ (Figure $3 \mathrm{a}-\mathrm{I}$ ). The $\theta$ value at SPR of $3.5 \mathrm{MPa}$ was less than $\theta$ values at $\Psi$ of $-33 \mathrm{kPa}$ in all tillage and cropping systems (Figure $3 \mathrm{a}-\mathrm{I}, \mathrm{a}-\mathrm{II})$. Also in this layer, it was observed that $\theta$ values at SPR of $2 \mathrm{MPa}$ was equivalent to $\theta$ values at $\Psi$ of $-33 \mathrm{kPa}$ in both crop succession and rotation treatments (Figure 3a-II). The $\theta$ values at SPR of $3.5 \mathrm{MPa}$ in $\mathrm{CT}$ did not differ from the $\theta$ values at $\Psi$ of $-1500 \mathrm{kPa}$, indicating that for this soil structural condition, an increase in the critical SPR value from 2 to $3.5 \mathrm{MPa}$ cannot be recommended. However, in the $0.0-0.10 \mathrm{~m}$ layer, the $\theta$ values at SPR of $3.5 \mathrm{MPa}$ were higher than at $\Psi$ of $-1500 \mathrm{kPa}$ in all tillage systems (Figure 3a-I).
In the 0.10-0.20 m layer, $\theta$ at SPR of $2 \mathrm{MPa}$ was higher than the water content at $\Psi$ of $-10 \mathrm{kPa}$ in treatments $\mathrm{MTC}_{3}$ and $\mathrm{NT}_{11}$. However, $\theta$ at $\Psi$ of $-10 \mathrm{kPa}$ was identical with q at SPR of $2 \mathrm{MPa}$ in the $0.10-0.20 \mathrm{~m}$ layer of treatments $\mathrm{CT}, \mathrm{MTC}_{1}$ and $\mathrm{NT}_{24}$ (Figure 3b-I). This indicates that the critical threshold of 2 MPa SPR cannot be considered an appropriate value for any of the tillage systems, since this value suggests, regardless of the tillage system, that $\theta$ must be greater than or equal to field capacity ( $\Psi$ of $-10 \mathrm{kPa}$ ) to prevent root growth restrictions. In the same layer, the $\theta$ at SPR of $2 \mathrm{MPa}$ was greater than $\theta$ at $\Psi$ of $-33 \mathrm{kPa}$ in all tillage and cropping systems, and in some cases lower (CT, $\mathrm{MTC}_{1}, \mathrm{NT}_{24}$ and under crop succession and rotation) or higher $\left(\mathrm{MTC}_{3}\right.$ and $\mathrm{NT}_{11}$ ) than the amount obtained at $\Psi$ of $-10 \mathrm{kPa}$ (Figure 3b-I,b-II). Again, this indicates that in all tillage and cropping systems, the use of a critical threshold of $2 \mathrm{MPa}$ SPR would already result in limited plant growth and development, however, this limitation was not reflected in the soybean and wheat 


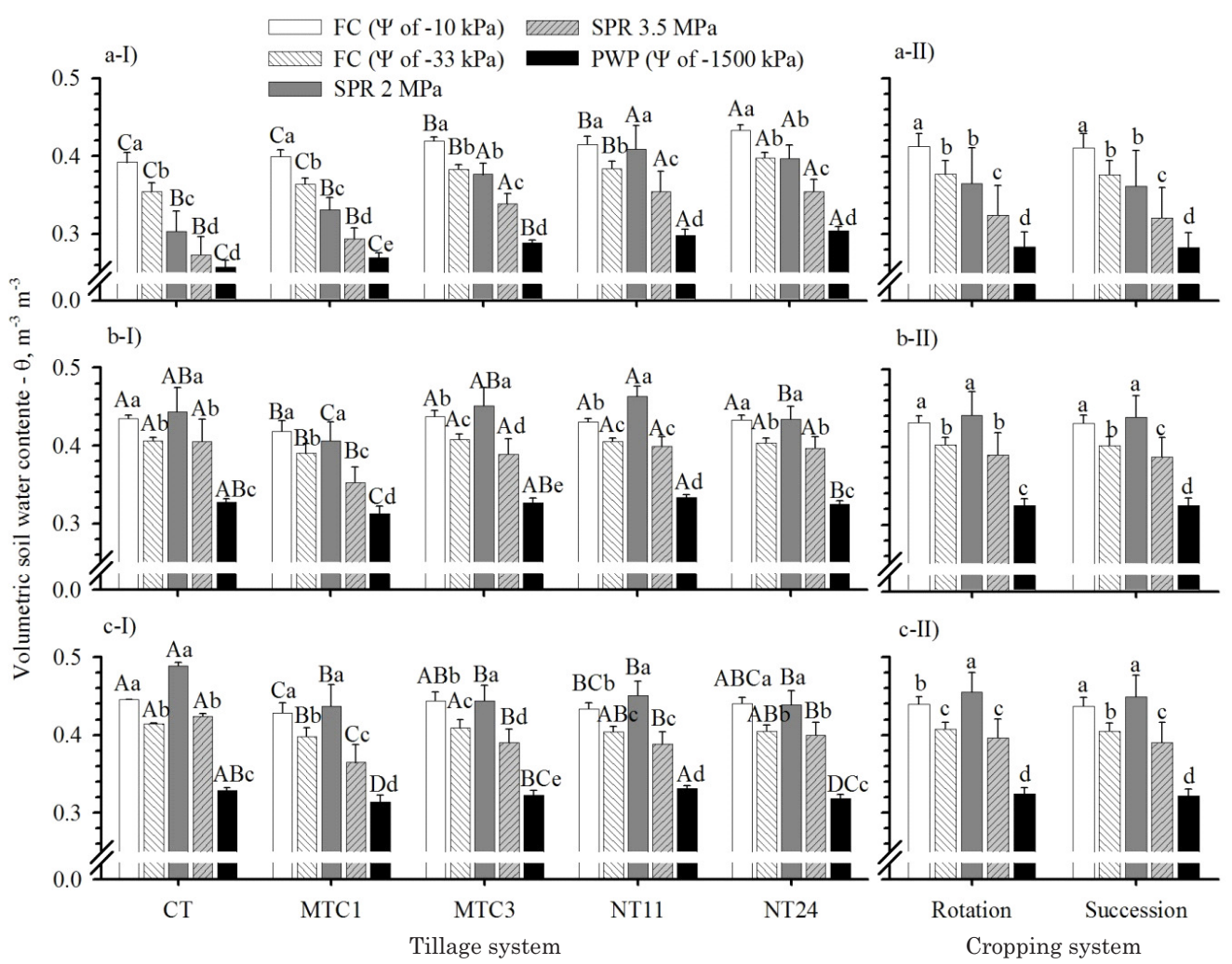

Figure 3. Volumetric water content at field capacity (matric potential of -10 and $-33 \mathrm{kPa}$ ), permanent wilting point (matric potential of $-1500 \mathrm{kPa}$ ) limits and soil penetration resistance at 2 and $3.5 \mathrm{MPa}$, in the 0.0 $0.10 \mathrm{~m}$ (a) 0.10-0.20 $\mathrm{m}$ (b) and 0.20-0.30 $\mathrm{m}$ (c) layers under different tillage (I) and cropping systems (II) in a Rhodic Eutrudox. Means followed by the same letter, uppercase between tillage systems, and lowercase in the same tillage or cropping systems, do not differ by the Tukey test $(p<0.05)$. CT: conventional tillage system; MTC $_{1}$ : minimum tillage, annual chiseling; $\mathbf{M T C}_{3}$ : minimum tillage, chiseled every three years; $\mathrm{NT}_{11}$ : no-tillage for 11 years; $\mathrm{NT}_{24}$ : no-tillage for 24 years. The vertical bars indicate the standard deviation from mean value due to tillage and/or cropping systems.

yields of this cropping season (Moraes, 2013) nor in the grain yield recorded over two decades in this experiment (Franchini et al., 2012). The at SPR of $3.5 \mathrm{MPa}$, regardless of tillage and cropping systems, was lower than the water content at $\Psi$ of $-10 \mathrm{kPa}$, indicating that this threshold ensures better soil physical conditions for plant growth and development. For the same Oxisol, Betioli Júnior et al. (2012) reported that a SPR value of $2 \mathrm{MPa}$ overestimated the limitations for root growth and development in a continuous NT system, while a critical SPR greater than $2 \mathrm{MPa}$ resulted in a non-limiting water range consistent with the soil physical quality under NT.

In the $0.20-0.30 \mathrm{~m}$ layer, the $\theta$ at $\Psi$ of $-10 \mathrm{kPa}$ was lower than the value obtained at SPR of $2 \mathrm{MPa}$ in treatments $\mathrm{MTC}_{3}$ and $\mathrm{NT}_{11}$, but equal to the value obtained in the treatments CT, $\mathrm{MTC}_{1}$ and $\mathrm{NT}_{24}$ at the same SPR (Figure 3c-I). The $\theta$ at $\Psi$ of $-10 \mathrm{kPa}$ suction was lower than the value obtained at SPR of $2 \mathrm{MPa}$ under crop rotation, however, it was equal to the value obtained at SPR of $2 \mathrm{MPa}$ under crop succession (Figure 3c-II). These results indicate that the use of a critical SPR value of $2 \mathrm{MPa}$ for all tillage and cropping systems in this layer is related to strong physical restrictions to root penetration, which could reduce the extraction of water and nutrients by plants. Therefore, by increasing the critical limit of SPR from 2 to $3.5 \mathrm{MPa}$, we observed that the soil water content in all tillage and cropping systems was lower than that obtained at $\Psi$ of $-10 \mathrm{kPa}$ (Figure 3c-I,c-II). Thus, using a critical SPR limit of 3.5 MPa in the $0.20-0.30 \mathrm{~m}$ layer indicates adequate soil physical conditions to extract water and nutrients and no physical barriers to root penetration, thus corroborating the results of soybean and wheat grain yield (Moraes, 2013) and also yield stability in a long-term NT system studied by Franchini et al. (2012).

Analyzing the $\Psi$ when SPR value reached 2 and $3.5 \mathrm{MPa}$ in the three layers evaluated, a significant influence of the tillage systems (Figure 4-I) but not the cropping systems was observed (Figure 4-II). In the 0.0-0.10 m layer, the $\Psi$ values in the $\mathrm{MTC}_{3}, \mathrm{NT}_{11}$ and $\mathrm{NT}_{24}$ managements were close to $-33 \mathrm{kPa}$ at $\mathrm{SPR}$ of $2 \mathrm{MPa}$. In these tillage systems, extending the critical limit of SPR to 3.5 MPa resulted in $\Psi$ near $-150 \mathrm{kPa}$ (Figure 4a-I). The change of SPR from 2 to 


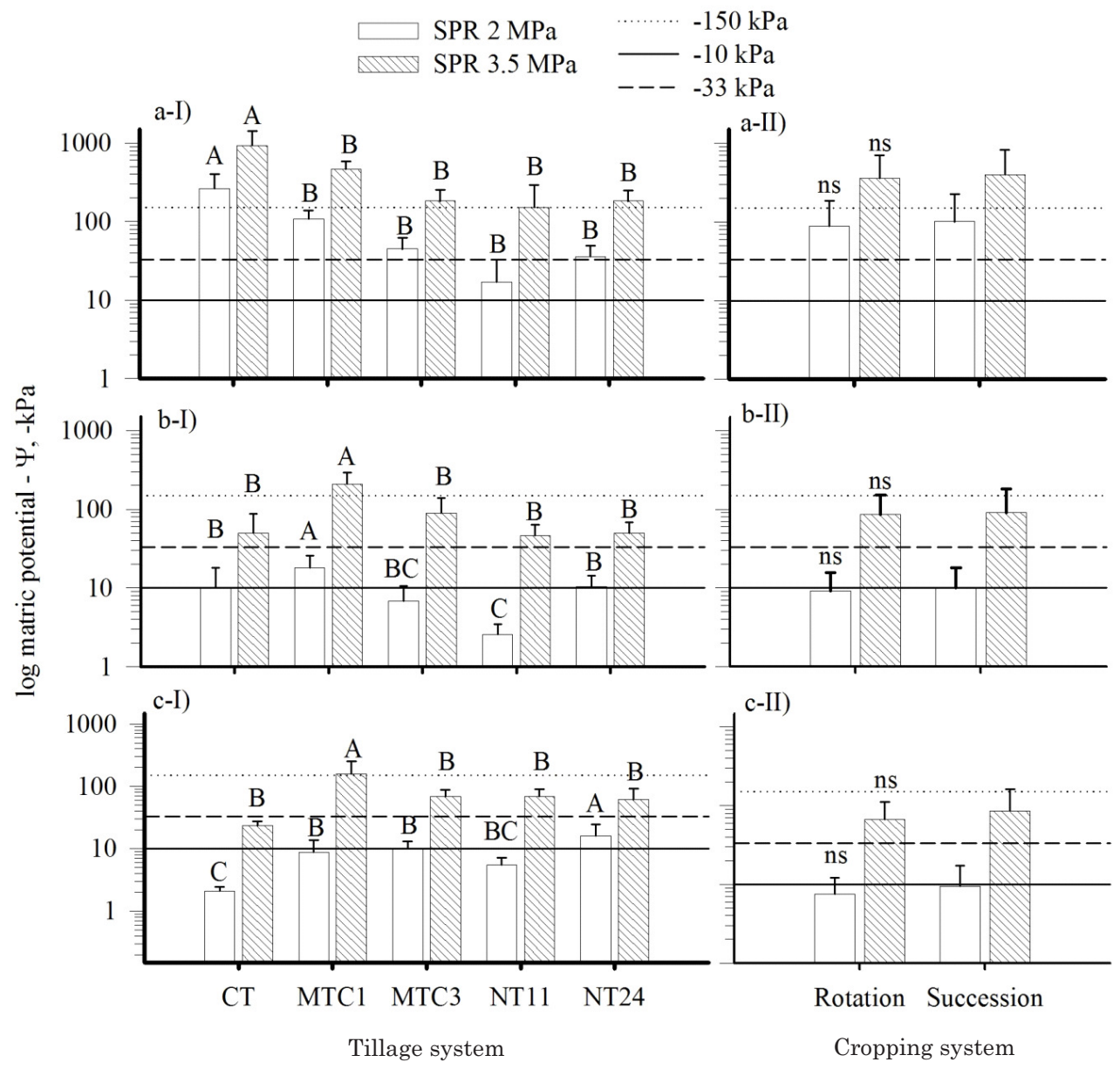

Figure 4. Soil water matric potential when the soil penetration resistance reaches 2 and $3.5 \mathrm{MPa}$ in the layers 0.0-0.10 m (a); 0.10-0.20 $\mathrm{m}$ (b) and 0.20-0.30 m (c) for tillage (I) and cropping systems (II). Means followed by the same letter, uppercase between tillage systems, and lowercase in the same tillage or cropping system, do not differ by Tukey's test $(\mathbf{p}<0.05)$. CT: conventional tillage; MT $_{1}$ : minimum tillage, annual chiseling; $\mathrm{MT}_{3}$ : minimum tillage, chiseled every three years; $\mathrm{NT}_{11}$ : no-tillage for 11 years; $\mathrm{NT}_{24}$ : no-tillage for 24 years. Vertical bars indicate standard deviation from the mean.

3.5 MPa in the 0.0-0.10 m layer in treatments CT and $\mathrm{MTC}_{1}$ was inadequate because the $\Psi$ increased from -260 to $-920 \mathrm{kPa}$ and -108 to $-460 \mathrm{kPa}$, respectively, indicating that, in soils degraded by the annual intensive tillage with disk harrow (CT), the critical limit of SPR should be maintained at $2 \mathrm{MPa}$, while in $\mathrm{MTC}_{1}$, the limiting value of SPR should be less than 3.5 MPa.

In the 0.10-0.20 m layer and considering a SPR value of $2 \mathrm{MPa}$, the $\Psi$ values in all tillage systems were higher (less negative) than $-18 \mathrm{kPa}$, as observed in $\mathrm{MTC}_{1}$ (Figure 4b-I). The determination of SPR at $3.5 \mathrm{MPa}$ indicates that the soil could reach a $\Psi$ of $-50 \mathrm{kPa}$ in treatments $\mathrm{CT}, \mathrm{NT}_{11}$ and $\mathrm{NT}_{24} ;-88$ $\mathrm{kPa}$ in $\mathrm{MTC}_{3}$ and $-200 \mathrm{kPa}$ in $\mathrm{MTC}_{1}$, with no physical limitations to root growth (Figure 4b-I). Considering the irrigation management monitored with a tensiometer in clay soils under soybean, irrigation should be initiated when the soil reaches a $\Psi$ of - $70 \mathrm{kPa}$ (Guerra \& Antonini, 1997). Collares (1994) studied the performance of soybean under different irrigation levels and noted that soybean yields were not affected by a water deficit up to a $\Psi$ of $-150 \mathrm{kPa}$ in the 0.0-0.20 m layer.

In the 0.20-0.30 m layer and considering a SPR value of $2 \mathrm{MPa}$, the $\Psi$ in NT24 was $-15 \mathrm{kPa}$, but less than $10 \mathrm{kPa}$ in the other tillage and cropping systems (Figure 4c-I,c-II). This indicates that $\theta$ should be higher than the field capacity to prevent a reduction of the root volume or even a barrier to root penetration in the soil. In $\mathrm{MTC}_{3}, \mathrm{NT}_{11}$ and $\mathrm{NT}_{24}$, the SPR values reached $3.5 \mathrm{MPa}$ for water tension below $\Psi$ of $-70 \mathrm{kPa}$. In treatment MTC1, a SPR value of 3.5 MPa was associated with a $\Psi$ of $-160 \mathrm{kPa}$. However, in treatment CT, a $\Psi$ of $-20 \mathrm{kPa}$ was obtained at SPR of $3.5 \mathrm{MPa}$ (Figure 4c-I). This reduction in $\Psi$ may be attributed to soil compaction in this treatment, that is, physical restrictions to plant growth and development occurred in this tillage system, resulting in a lower soybean grain yield (656 kg ha-1) than in $\mathrm{NT}_{24}$ (Moraes, 2013). 
This indicates that the use of a SPR value of $3.5 \mathrm{MPa}$ could be adequate for this soil under long-term NT or periodic chiseling every three years.

The critical SPR limit of $2 \mathrm{MPa}$ is a very conservative threshold and not compatible with the results of soybean and wheat grain yield (Figure 5). The soybean and wheat grain yield was not significantly related to SPR at $\Psi$ of $-33 \mathrm{kPa}$ in the 0.10-0.20 m layer, which is the most important layer for soil physical quality (Debiasi et al., 2010), and in most cases, the one with the highest degree of compaction in NT systems (Franchini et al., 2011). Nevertheless, we observed that, regardless of the tillage system, all SPR values were higher than 2 $\mathrm{MPa}$, and the yield in the CT plots was lower than in the other tillage systems. The wheat and soybean grain yield was higher in $\mathrm{NT}_{24}$ than in $\mathrm{CT}$, even at SPR values of $3 \mathrm{MPa}$. This indicates that the critical limit of SPR should be readjusted according to the tillage system. With the exception of soybean grain yield in CT, there were no yield losses due to physical restrictions to crop growth in the other tillage systems (Moraes, 2013). A comparison of these findings with published results showed that the soybean and wheat yields in this study were similar to the average grain yield of these crops in the 2011/12 growing season in the State of Paraná, Brazil (CONAB, 2012). In addition, the soybean, corn and wheat yields in this experiment, monitored over two decades, were stabilized from the seventh year under NT onwards (Franchini et al., 2012).

Analyzing $\theta$ and $\Psi$ in the three layers evaluated, it was confirmed that the adoption of a threshold of

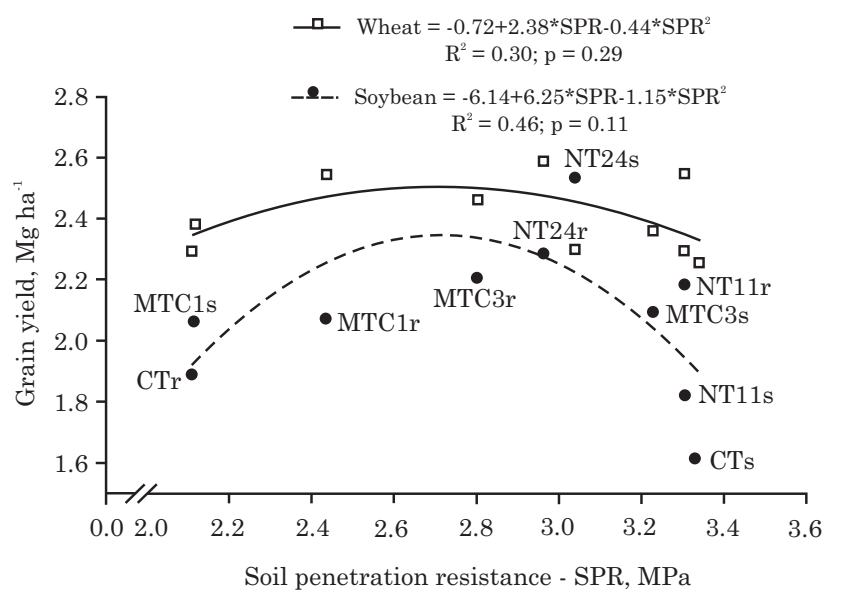

Figure 5. Soybean and wheat grain yield as related to soil penetration resistance at a matric potential of $-33 \mathrm{kPa}$ in the $0.10-0.20 \mathrm{~m}$ layer under the tillage systems: CT- conventional tillage; MTC $_{1}$ - minimum tillage with annual chiseling; $\mathrm{MTC}_{3}-$ minimum tillage with chiseling every three years; $\mathrm{NT}_{11}$-no-tillage for 11 years; $\mathrm{NT}_{24}$ no-tillage for 24 years; $r$ - crop rotation; $\mathrm{s}$ - crop succession.
3.5 MPa for SPR instead of $2 \mathrm{MPa}$ would be suitable for production systems under consolidated $\mathrm{NT}\left(\mathrm{NT}_{11}\right.$ and $\left.\mathrm{NT}_{24}\right)$ or soil chiseling every three years $\left(\mathrm{MTC}_{3}\right)$. It is important to mention that the critical threshold SPR value of 3.5 MPa may not be suitable for systems with intensive soil tillage, such as CT with heavy plowing and harrowing or annual soil chiseling $\left(\mathrm{MTC}_{1}\right)$.

Also evaluating the SPR status at a PAW of 0.7 (Carlesso, 1995; Santos \& Carlesso, 1998), i.e., when $30 \%$ of the water-holding capacity (between field capacity and permanent wilting point) was extracted from all three layers of the soil profile, the tillage systems had a significant effect but not the cropping systems (Figure 6).

In the 0.0-0.10 m layer, SPR (at PAW = 0.7) was highest in $\mathrm{NT}_{11}(2.7 \mathrm{MPa})$ and lowest in $\mathrm{CT}$ and $\mathrm{MTC}_{1}$ with SPR of 0.95 and $1.4 \mathrm{MPa}$, respectively. In the 0.10-0.20 m layer, the treatments $\mathrm{NT}_{11}$ and $\mathrm{NT}_{24}$ had $\mathrm{SPR}$ values of 3.5 and $3.3 \mathrm{MPa}$ (at $\mathrm{PAW}=0.7$ ), respectively. Also in this layer, the management systems with soil chiseling, $\mathrm{MTC}_{1}$ and $\mathrm{MTC}_{3}$, had SPR values of 2.5 and $3.0 \mathrm{MPa}$, respectively. For the 0.20 $-0.30 \mathrm{~m}$ layer, the SPR values were 3.1 and $3.3 \mathrm{MPa}$ in $\mathrm{NT}_{11}$ and $\mathrm{NT}_{24}$, respectively. However, in the same layer, $\mathrm{MTC}_{1}$ and $\mathrm{MTC}_{3}$ resulted in SPR values of 2.8 and 2.9 $\mathrm{MPa}$, respectively (Figure 6). Carlesso et al. (1997) suggested a PAW value of 0.6 as critical limit to avoid reductions in leaf area. These authors found that sorghum plants began to wither at PAW below 0.5 . Therefore, to prevent conditions at which plants would be subjected to water stress down to a depth of $0.30 \mathrm{~m}$ of this soil type, the SPR values at PAW of 0.7

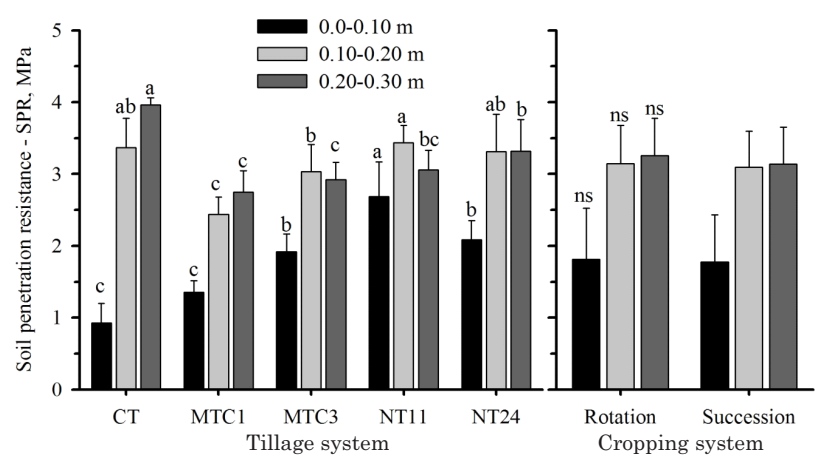

Figure 6. Soil penetration resistance of the tillage and cropping systems when the fraction of plant-available water reached 0.7 . ns Not significant in each layer by the F-test $(p<0.05)$; Means followed by the same letter, uppercase between tillage systems, and lowercase in the same tillage or cropping systems, do not differ by Tukey's test $(p<0.05)$. CT: conventional tillage system; MTC $_{1}$ : minimum tillage, annual chiseling; $\mathrm{MTC}_{3}$ : minimum tillage, chiseled every three years; $\mathrm{NT}_{11}$ : no-tillage for 11 years; $\mathrm{NT}_{24}$ : no-tillage for 24 years. Vertical bars indicate standard deviation from the mean. 
should be adjusted, according to the tillage system. Considering the results of soybean and wheat grain yield over two decades (Franchini et al., 2012) and of the harvest of the 2011/2012 growing season (Moraes, 2013), an increase in the critical SPR limits as a function of tillage system is recommended. In this context, critical SPR values up to $3 \mathrm{MPa}$ could be used in management systems with annual chiseling or chiseling every three years $\left(\mathrm{MTC}_{1}\right.$ and $\left.\mathrm{MTC}_{3}\right)$. In consolidated NT systems $\left(\mathrm{NT}_{11}\right.$ and $\left.\mathrm{NT}_{24}\right)$, SPR thresholds up to $3.5 \mathrm{MPa}$ can be applied. However, it is important to emphasize that in systems with heavy tillage (CT), the critical SPR value of $2 \mathrm{MPa}$ should not be altered, because the results of the soybean grain yield indicated a yield loss in the $\mathrm{NT}_{24}$ treatment at this SPR level (Moraes, 2013), resulting in water restrictions in the soil profile, and in CT systems the use of the critical SPR at PAW of 0.7 may not be appropriate.

\section{CONCLUSIONS}

1. For the studied Rhodic Eutrudox with very clayey texture under continuous no-tillage, the critical value of soil penetration resistance should be increased from the actual 2.0 to $3.5 \mathrm{MPa}$.

2. For systems under minimum tillage, with annual chiseling or chiseling every three years, on a Rhodic Eutrudox with very clayey texture, the limiting value of soil penetration resistance should be increased to $3 \mathrm{MPa}$.

3. However, for conventional tillage systems with annual tilling of a Rhodic Eutrudox with very clayey texture, the critical value of soil penetration resistance of $2 \mathrm{MPa}$ should be maintained.

4. Soil penetration resistance was not altered by the cropping systems, i.e., by the crop succession systems: [wheat (Triticum aestivum L.)/soybean (Glicine $\max L$.)] and/or crop rotation [white lupine (Lupinus albus L.) and radish (Raphanus sativus L.)/ maize (Zea mays L.) - oat (Avena strigosa Schreb.)/ soybean - wheat/soybean - wheat/soybean].

5. The positive effect of soil chiseling of a Rhodic Eutrudox with very clayey texture on soil penetration resistance lasted at most 10 months in relation to continuous no-tillage. Thus, continuous no-tillage could be the best management option for this soil type.

\section{LITERATURE CITED}

ABREU, S.L.; REICHERT, J.M. \& REINERT, D.J. Escarificação mecânica e biológica para a redução da compactação em Argissolo franco-arenoso sob plantio direto. R. Bras. Ci. Solo, 28:519-531, 2004.
ASSIS, R.L.; LAZZZARINI, G.D.; LANÇAS, K.P. \& CARGNELUTTI FILHO, A. Avaliação da resistência do solo à penetração em diferentes solos com a variação do teor de água. Eng. Agric., 29:558-568, 2009.

BERGAMIN, A.C.; VITORINO, A.C.T.; LEMPP, B.; SOUZA, C.M.A. \& SOUZA, F.R. Anatomia radicular de milho em solo compactado. Pesq. Agropec. Bras., 45:299-305, 2010.

BETIOLI JÚNIOR, E.; MOREIRA, W.H.; TORMENA, C.A.; FERREIRA, C.J.B.; SILVA, A.P. \& GIAROLA, N.F.B. Intervalo hídrico ótimo e grau de compactação de um Latossolo Vermelho após 30 anos sob plantio direto. R. Bras. Ci. Solo, 36:971-982, 2012.

CARLESSO, R. Absorção de água pelas plantas: Água disponível versus extraível e a produtividade das culturas. Ci. Rural, 25:183-188, 1995.

CARLESSO, R.; PEITER, M.X.; PETRY, M.T. \& WOSCHICK, D. Resposta do sorgo granífero a déficits hídricos aplicados durante o ciclo de desenvolvimento da cultura. Ci. Rural, 27:211-215, 1997.

COLLARES, G.L. Resposta da soja a diferentes níveis de manejo da irrigação. Santa Maria, Universidade Federal de Santa Maria, 1994. 65p. (Dissertação de Mestrado)

COMPANHIA NACIONAL DE ABASTECIMENTO - CONAB. Acompanhamento da safra Brasileira: Grãos 2011/2012, Oitavo levantamento. Brasília, 2012. Available at: <http:/ /www.conab.gov.br/OlalaCMS/uploads/arquivos/ 12_05_10_08_49_52_boletim_maio_2012.pdf > . Accessed: 07 Jan. 2013.

COSTA, M.S.S.M.; PIVETTA, L.A.; COSTA, L.A.M.; PIVETTA, L.G.; CASTOLDI, G. \& STEINER, F. Atributos físicos do solo e produtividade do milho sob sistemas de manejo e adubações. R. Bras. Eng. Agríc., 15:810-815, 2011.

DEBIASI, H.; LEVIEN, R.; TREIN, C.R.; CONTE, O. \& KAMIMURA, K.M. Produtividade de soja e milho após coberturas de inverno e descompactação mecânica do solo. Pesq. Agropec. Bras., 45:603-612, 2010.

DIAS JUNIOR, M.S. \& PIERCE, F.J. O processo de compactação do solo e sua modelagem. R. Bras. Ci. Solo, 20:175-182, 1996.

DRESCHER, M.S.; ELTZ, F.L.F.; DENARDIN, J.E. \& FAGANELLO, A. Persistência do efeito de intervenções mecânicas para a descompactação de solos sob plantio direto. R. Bras. Ci. Solo, 35:1713-1722, 2011.

EMPRESA BRASILEIRA DE PESQUISA AGROPECUÁRIA EMBRAPA. Manual de métodos de análise de solo. 2.ed. Rio de Janeiro, 1997. 212p.

FRANCHINI, J.C.; DEBIASI, H.; SACOMAN, A.; NEPOMUCENO, A.L. \& FARIAS, J.R.B. Manejo do solo para redução das perdas de produtividade pela seca. Londrina, Embrapa Soja, 2009. 39p. (Embrapa Soja. Documentos, 314)

FRANCHINI, J.C.; COSTA, J.M.; DEBIASI, H. \& TORRES, E. Importância da rotação de culturas para a produção agrícola sustentável no Paraná. Londrina, Embrapa Soja, 2011. 52p. (Embrapa Soja. Documentos, 327) 
FRANCHINI, J.C.; DEBIASI, H.; BALBINOT JUNIOR, A.A.; TONON, B.C.; FARIAS, J.R.B.; OLIVEIRA, M.C.N. \& TORRES, E. Evolution of crop yields in different tillage and cropping systems over two decades in southern Brazil, Field Crop. Res., 137:178-185, 2012.

GENRO JUNIOR, S.A.; REINERT, D.J.; REICHERT, J.M. \& ALBUQUERQUE, J.A. Atributos físicos de um Latossolo Vermelho e produtividade de culturas cultivadas em sucessão e rotação. Ci. Rural, 39:65-73, 2009.

GUERRA, A.F. \& ANTONINI, J.C.A. Irrigação suplementar para a cultura de soja. In EMPRESA BRASILEIRA DE PESQUISA AGROPECUÁRIA - EMBRAPA. Centro de Pesquisa Agropecuária dos Cerrados. Relatório técnico anual do Centro de Pesquisa Agropecuária dos Cerrados 1991 a 1995. Planaltina, 1997. p.99-100.

KLEIN, V.A.; REICHERT, J.M. \& REINERT, D.J. Água disponível em um Latossolo Vermelho argiloso e murcha fisiológica de culturas. R. Bras. Eng. Agríc., 10:646-650, 2006.

LANZANOVA, M.E.; ELTZ, F.L.F.; NICOLOSO, R.S.; AMADO, T.J.C.; REINERT, D.J. \& ROCHA, M.R. Atributos físicos de um Argissolo em sistemas de culturas de longa duração sob semeadura direta. R. Bras. Ci. Solo, 34:1333-1342, 2010 .

LIMA, C.L.R.; MIOLA, E.C.C.; TIMM, L.C.; PAULETTO, E.A. \& SILVA, A.P. Soil compressibility and least limiting water range of a constructed soil under cover crops after coal mining in Southern Brazil. Soil Till. Res., 124:190-195, 2012.

MORAES, M.T. Qualidade física do solo sob diferentes tempos de adoção e de escarificação do sistema plantio direto e sua relação com a rotação de culturas. Santa Maria, Universidade Federal de Santa Maria, 2013. 205p. (Dissertação de Mestrado)

MORAES, M.T.; DEBIASI, H.; FRANCHINI, J.C. \& SILVA, V.R. Correction of resistance to penetration by pedofunctions and a reference soil water content. R. Bras. Ci. Solo, 36:1395-1406, 2012.

MORAES, M.T.; DEBIASI, H.; FRANCHINI, J.C. \& SILVA, V.R. Soil penetration resistance in a Rhodic Eutrudox affected by machinery traffic and soil water content. Eng. Agríc., 33:748-757, 2013.

PICCININ, J.L. Modificações no perfil de solo sob plantio direto contínuo e com intervenções mecânicas sob sucessão e rotação de culturas. Campinas, Universidade Estadual de Campinas, 2005. 112p. (Tese de Doutorado)
REICHERT, J.M.; SUZUKI, L.E.A.S. \& REINERT, D.J. Compactação do solo em sistemas agropecuários e florestais: Identificação, efeitos, limites críticos e mitigação In: CERRETA, C.A.; SILVA, L.S. \& REICHERT, J.M., eds. Tópicos em ciência do solo. Viçosa, MG, Sociedade Brasileira de Ciência do Solo, 2007. v.5. p.49-134.

ROS, V.V.; SOUZA, C.M.A.; VITORINO, A.C.T. \& RAFULL, L.Z.L. Oxisol resistance to penetration in no-till system after sowing. Eng. Agríc., 31:1104-1114, 2011.

SANTOS, H.G.; JACOMINE, P.K.T.; ANJOS, L.H.C.; OLIVEIRA, V.A.; LUBRERAS, J.F.; COELHO, M.R.; ALMEIDA, J.A.; CUNHA, T.J.F. \& OLIVEIRA, J.B., eds. Sistema brasileiro de classificação de solos. 3.ed. Brasília, Embrapa, 2013. 353p.

SANTOS, R.F. \& CARLESSO, R. Déficit hídrico e os processos morfológicos e fisiológicos das plantas. R. Bras. Eng. Agríc., 2:287-294, 1998.

SAS LEARNING EDITION. Getting started with the SAS Learning Edition. Cary, 2002. 200p.

SOIL SURVEY STAFF. Keys to soil taxonomy. 11.ed. Washington, DC, USDA/NRCS, 2010. 338p.

SILVA, A.P.; TORMENA, C.A.; FIDALSKI, J. \& IMNHOFF, S. Funções de pedotransferência para as curvas de retenção de água e de resistência do solo à penetração. R. Bras. Ci. Solo, 32:1-10, 2008.

SILVA, V.R.; REICHERT, J.M.; REINERT, D.J. \& BORTOLUZZI, E.C. Soil water dynamics related to the degree of compaction of two Brazilian Oxisols under notillage. R. Bras. Ci. Solo, 33:1097-1104, 2009.

SILVA, S.G.C.; SILVA, A.P.; GIAROLA, N.F.B.; TORMENA, C.A. \& SÁ, J.C.M. Temporary effect of chiseling on the compaction of a Rhodic Hapludox under no-tillage. R. Bras. Ci. Solo, 36:547-555, 2012.

TAVARES FILHO, J.; FONSECA, I.C.B.; RIBON, A.A. \& BARBOSA, G.M.C. Efeito da escarificação na condutividade hidráulica saturada de um Latossolo Vermelho sob plantio direto. Ci. Rural, 36:996-999, 2006.

TORMENA, C.A.; SILVA, A.P. \& LIBARDI, P.L. Caracterização do intervalo hídrico ótimo de um Latossolo Vermelho Roxo sob plantio direto. R. Bras. Ci. Solo, 22:573-581, 1998.

TORMENA, C.A.; ARAÚJO, M.A.; FIDALSKI, J. \& COSTA, J.M. Variação temporal do intervalo hídrico ótimo de um Latossolo Vermelho distroférrico sob sistemas de plantio direto. R. Bras. Ci. Solo, 31:211-219, 2007. 